\title{
Application of an improved vegetation index based on the visible spectrum in the diagnosis of degraded pastures: Implications for development
}

\author{
Thiago Luiz da Silva Quinaia ${ }^{1}$ | Renato Farias do Valle Junior ${ }^{1,2}$ () | \\ Victor Peçanha de Miranda Coelho ${ }^{1}$ (ㅇ | Rafael Carvalho da Cunha ${ }^{1}$ | \\ Carlos Alberto Valera ${ }^{2,3}$ | Luís Filipe Sanches Fernandes ${ }^{2,4}$ () | \\ Fernando António Leal Pacheco ${ }^{2,5}$
}

${ }^{1}$ Geoprocessing Laboratory, Federal Institute of Triângulo Mineiro, Uberaba Campus, Uberaba, Brazil

${ }^{2}$ POLUS-Grupo de Política de Uso do Solo, Universidade Estadual Paulista (UNESP), Jaboticabal, Brazil

${ }^{3}$ Regional Coordination of the Environmental Justice Prosecutor's Office of the Paranaíba and Lower Rio Grande River Basins, Uberaba, Brazil

${ }^{4}$ Center for Research and Agro-environmental and Biological Technologies, University of Trás-os-Montes e Alto Douro, Vila Real,

Portugal

${ }^{5}$ Center of Chemistry of Vila Real, University of Trás-os-Montes e Alto Douro, Vila Real, Portugal

\section{Correspondence}

Fernando António Leal Pacheco, Center of Chemistry of Vila Real, University of Trás-osMontes e Alto Douro, Ap. 1013, 5001-801 Vila Real, Portugal.

Email: fpacheco@utad.pt

\section{Funding information}

Conselho Nacional de Desenvolvimento Científico e Tecnológico, Grant/Award Number: 307921/2018-2; Fundação para a Ciência e a Tecnologia, Grant/Award Numbers: UIDB/00616/2020, UIDB/04033/2020

\begin{abstract}
Inadequate pasture management causes land degradation through reduction of grass, increased presence of invasive plants or pests, compaction, erosion, and nutrient deficiency. The recognition of pasture degradation is therefore essential. Remote sensing satellite systems allow us to do so at regional-to global scales. A struggle is in progress nowadays is to improve detection accuracy and implement high-resolution surveys at farm scales using low-cost unmanned aerial vehicles (UAVs). The pasture imagery can be translated into maps of degraded pasture using the popular NDVI as diagnostic parameter, but their generation using a UAV requires a high-cost NIR sensor, while the struggle is to use low-cost UAVs equipped with RGB cameras. The first step to recognize degraded pastures using RGB cameras is to define a suitable vegetation index. Thus, the purpose of this study was to present the total brightness quotient of red (TBQR), green (TBQG), and blue (TBQB) bands. The test to the index resorted to LANDSAT-8 satellite images captured over the environmental protection area of Uberaba River basin (Minas Gerais, Brazil) in the 2017-2019 period. The images were not captured by a UAV because the equipment was not then available. The results were promising given the large detection accuracy (88.63\%) of the TBQG and the high (0.965) correlation between TBQG and NDVI. Besides, the TBQ-based areas of degraded pasture (17,486.3-25,180.1 hectares) were larger than the NDVI counterparts $(12,066.9$ hectares). This is an additional reason to oversight degraded pastures based on the TBQs, as they seek for improved environmental compliance and economic development.
\end{abstract}

KEYWORDS

Google Earth engine, NDVI, pasture degradation, remote sensing, total brightness quotient, unmanned aerial vehicles 


\section{1 | INTRODUCTION}

The nutrients required by animals are $90 \%$ obtained from pastures (Euclides et al., 2010). Notwithstanding the importance of pastures for feeding livestock, around 108 million hectares of existing fenced pastures in Brazil are degraded or in degradation (EMBRAPA, 2014; EMBRAPA Territorial, 2018), which means $60 \%$ of pastureland in this Country.

Pasture degradation is a slow gradual process. It reduces plant's vigor and hence the capacity of forage plants to sustain the production and quality demanded by the animals. It also weakens the resilience to pests, diseases, and the invasion by non-palatable species (Zhumanova et al., 2018), which increases the chances of advanced degradation. A possible cause of pasture degradation is the lack of conservation practices (da Rocha Junior et al., 2016), namely adjustment of grazing rates (Fernandes et al., 2018; Postel, 1998), and the grazing on slopes $>20^{\circ}$, which can negatively affect soil stability and increase erosion (de Torres et al., 2019).

The causes of pasture degradation are well known, but their spatial and temporal dynamics remain poorly understood (Neves, 2017). An approach used to shed light over this issue relies on the coupling of remote sensing and geographic information systems, whereby the reflectance of pastures captured by sensors in cameras are used to estimate vegetation indices that correlate with the vigor of plants (de Torres et al., 2019; Lu \& Weng, 2007; Novo \& Ponzoni, 2001). The spectral response of pastures is difficult to grasp because of its dependence on many factors, such as species assemblage, soil type, or precipitation, which makes it extremely complex to classify pasture degradation using vegetation indices (Davidson et al., 2009). Nevertheless, several authors have used orbital sensors to analyze and map spatial and temporal variations in pasture fields using these proxies. The normalized difference vegetation index (NDVI) was the most widely used indicator (de Torres et al., 2019; Imukova et al., 2015; Li, Gao, et al., 2012; Li, Verburg, et al., 2012; Valle Júnior et al., 2019; Wiesmair et al., 2016). Other frequently used indexes include the enhanced vegetation index (EVI) (Junges et al., 2016; Karnieli et al., 2013); the soiladjusted vegetation index (SAVI) (Batista et al., 2020); the leaf area index (LAl) (Batista et al., 2020; Chen et al., 2019; Wang et al., 2019); the water use efficiency (WUE) (Fernandes et al., 2018); the net primary productivity (NPP) (Fernandes et al., 2018; Jiang et al., 2019; Sun et al., 2019); among others.

Many authors have also applied visible spectrum sensors (RGB) to quantify and map indicators of plant's biophysical state, such as aboveground biomass, plant vigor, productivity, and the LAl (Córcoles et al., 2013; Jang et al., 2020; Kim et al., 2019; Liu \& Pattey, 2010). Other studies indicated the RGB-based color vegetation index and the excess of green index, to diagnose vegetation cover (Arroyo et al., 2016; Beniaich et al., 2019). The green leaf index, on-the-otherhand, proved efficient to count plants (da Silva, 2017; Louhaichi et al., 2001), distinguish plant biomass from soil and residue (Meyer \& Neto, 2008), monitor vegetation fraction (Marcial-Pablo et al., 2019), and estimate the LAl as well as key growth indicators of rice ( $\mathrm{Li}$ et al., 2019; Qiu et al., 2020). However, to our best knowledge, no study attempted to diagnose pasture degradation using an RGB index. Eventually, the ease of obtaining reflectance data from the nearinfrared band using orbital satellites such as SENTINEL-2, LANDSAT-8, or MODIS hampered the development of such studies. However, comparing the detection efficiency among the visible (RGB) and nearinfrared (NIR) ranges would help to shed light on the potential of each range. Besides, the use of visible range vegetation indexes could boost the use of low-cost monitoring equipment, such as unmanned aerial vehicles (UAVs) at the canopy level and even smartphones at the leaf level, which have RGB but rarely NIR cameras.

The general purpose of this study was, therefore, to detect degraded pastures using the NDVI and the RGB-based color index (Cl) of Woebbecke et al. (1995), comparing the performances in the sequel. As a corollary, we aimed to improve the $\mathrm{Cl}$ for detection efficiency. The normalization through simple ratio processes applied to most vegetation indexes (Katsoulas et al., 2016) inherently generates asymptotic approaches to saturation, shrinking the range of linear relation between the index and biophysical characteristics, and hence the index's detection capacity (Gitelson, 2004). For example, the ratio between the difference and the sum used in the NDVI equation $[(\rho N I R-\rho r e d) /(\rho N I R+\rho r e d)]$ is barely capable of describing the plant's vigor when the target areas present high biomass (e.g., vegetation fraction $>60 \%$ ). In these cases, the $\rho N I R / \rho r e d$ ratio gets $>1$, both the numerator and denominator get close to equivalence, and the sensitivity of NDVI to $\rho$ NIR becomes insignificant. The loss of sensitivity caused by the 'difference over sum' normalization process also affects the $\mathrm{Cl}$ of Woebbecke et al. (1995). In this case, normalization occurs when a ratio is calculated between the target visible band and the sum of RGB bands [e.g., $B=\rho$ blue/(pred + ggreen $+\rho$ blue)]. The goal was to modify the denominator of $\mathrm{Cl}$ to improve its capability as a pasture degradation detector. The total brightness quotients of blue (TBQB), green (TBQG) and red (TBQR) developed in this study have contributed to accomplish that goal.

\section{2 | MATERIAL AND METHODS}

\subsection{Study area}

The present study was carried out in an environmental protection area (EPA) of the Uberaba River basin (Figure 1), which was legally instituted in 1999 through the Minas Gerais State Law No. 13,183/1999 (LEMG, 1999). Later, the municipality of Uberaba reinforced the protection through the Municipal Law 9892/2006, which creates the Municipal EPA of Uberaba River that includes measures for the protection of water resources, the riverside ecosystem, fauna, and remnants of native vegetation (savanna biome). The EPA occupies an area of approximately 52810.80 hectares, located between the geographical coordinates $19.51-19.74^{\circ}$ south and 47.64-47.98 ${ }^{\circ}$ west of Greenwich.

The population of Uberaba town has reached 295,988 inhabitants in 2020 . The water demanded by these people is mostly (95\%) supplied by the EPA's water resources (IBGE, 2020). The climate in the 
FIGURE 1 Location map with geographic coordinates indicating the position of Minas Gerais State in Brazil, of Uberaba town in the State, and of Uberaba River basin's environmental protection area (EPA) within the town limits. Topography is also illustrated along with the field sites (labeled circles) used to characterize pasture phytophysiognomies as well as to validate the remote sensed assessments of pasture degradation [Colour figure can be viewed at wileyonlinelibrary.com]
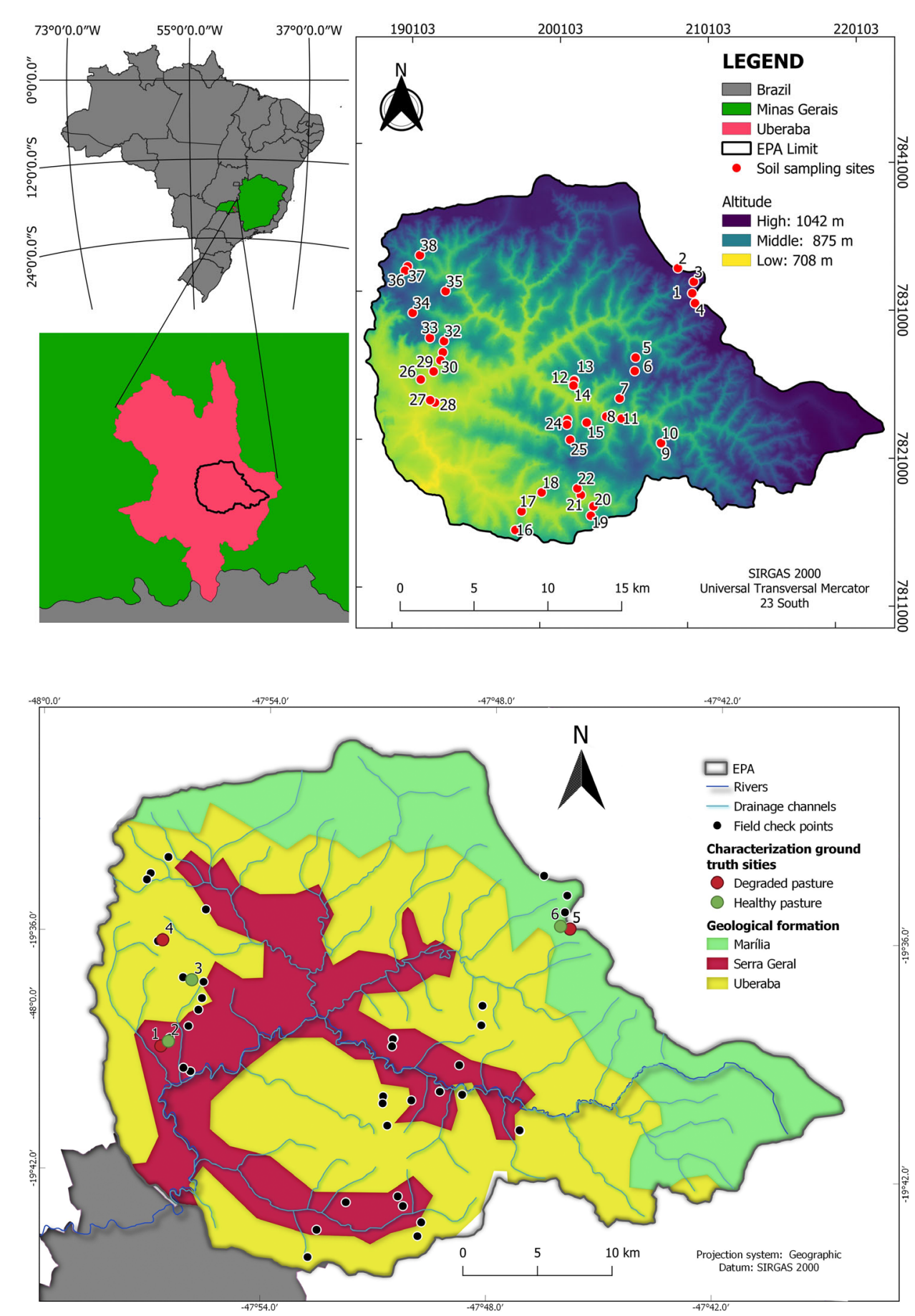

FIGURE 2 Geological map spanning the environmental protection area of the Uberaba River basin (EPA), with the identification of ground truth sites distributed within healthy (green circles) and degraded (red circles) pastures located in the Serra Geral, Marília, and Uberaba geologic Formations. The black dots represent random checkpoints used to validate the degradation assessments based on the remote sensed data (NDVI and RGB indices). Source: Modified from the Geological Map of Minas Gerais State, version of 2014 [Colour figure can be viewed at wileyonlinelibrary.com] region is Aw, described as tropical hot and humid with a cold dry winter (Beck et al., 2018). The climatic domain is semi-humid, with low precipitation in 4-5 months of the year and annual precipitation varying between 1300 and $1700 \mathrm{~mm}$. The rainy period corresponds to the hottest season, spanning the period from October to March. The dry season runs from April to September. Precipitation is more intense in December and January (Abdala, 2012).

The EPA's lithostratigraphic sequence comprises the Serra Geral (volcanic, composed of basalts), Uberaba, and Marília (sedimentary, composed of conglomerates, sandstones, siltstones, mudstones, and paleosols) Formations (Figure 2), shaped on undulated relief, which form the Bauru Group dated to the Cretaceous (Cruz, 2003). The predominant soil types in this plateau are characterized by medium textures that vary from sandy to clayey and evidence different levels of fertility (Nishiyama, 1998). According to the FAO's classification, these types of soil are called Latosols, Argisols, and Gleisols (Siqueira et al., 2017).

A large portion (55.45\%) of EPA's area is occupied by natural and planted pastures, dominated by the species Brachiaria brizantha cv. Marandú. In the Serra Geral, Marília, and Uberaba geological Formations, the occupations by pasture approach $8183.43,4882.53$, and 16219.72 ha, respectively (Table 1). 


\subsection{Data acquisition and workflow}

The prominent data sources used to perform the pasture degradation assessments are listed in Table 2. The land use and occupation map provided by the MapBiomas, namely collection 5 from to the year 2019 (MapBiomas, 2019), was used to delineate the pasture areas within the EPA. The delimitation of Serra Geral, Marilia, and Uberaba geological outcrops within the pasture areas was based on a map provided by the State System of Environment and Water Resources. The separate assessment of degraded pastures as function of geology was proven more efficient than the corresponding evaluation, not considering the role of geologic formations (Valle Júnior et al., 2019). In that regard, the setup of regression models to characterize pasture phytophysiognomies (e.g., Figure 5a-d below) was barely possible when the influence of geologic formation was ignored. The time-series of NDVI and RGB indices used to characterize (at ground truth sites) and classify (within the EPA) degraded pastures were retrieved from satellite images using two routines written in Javacript programming language by the authors. The diagnostic parameter resistance to penetration used to validate the remote sensed maps of degraded pasture was measured at checkpoints randomly distributed within the EPA but covering the three geologic formations.

The workflow started with the selection of ground truth sites within the EPA that clearly represented healthy and degraded pastures in the Serra Geral, Marilia, and Uberaba Formations (the selection details are explained in Section 2.3). Subsequently, time-series of NDVI and RGB vegetation indices were automatically retrieved from satellite images (Section 2.4) to define signatures for healthy and degraded pastures at the ground truth sites and to use them to classify pastures outside the ground truth sites (Section 2.5). Finally, the evaluations of pasture degradation derived from the RGB indices were compared with those resulting from the NDVI counterparts (Section 2.6), with the purpose to check consistency and performance among the classifications, while both the NDVI- and RGB-based maps of degraded pasture were validated at the checkpoints of Figure 2 using the resistance to penetration as diagnostic parameter (Section 2.7).

\section{3 | Identification of pasture phytophysiognomies in the EPA}

The signs of pasture degradation are not always evident. The frequency of invasive plants, the density of forage plants, and the percentage of soil cover by desirable plants are parameters that can be used for evaluation. The degradation of pastures in their most advanced stages is characterized by pervasive changes in the plant community dynamics, whereby desirable species (forage plants) are extensively replaced by others, of lesser or almost no forage value, and by the decline of forage productivity with reflexes in animal production (Townsend et al., 2012).

According to Macedo et al. (2014), the stages of pasture degradation can be recognized through physiological features detected in the plant and the soil. In the plant, the regrowth capacity, height of pasture, presence of areas without vegetation or with inhomogeneous coverage, and the infestation with invasive plants and pests are characteristic examples. In the soil, the key features can be soil compaction, erosion, and mineral deficiencies, mainly of nitrogen and phosphorus (FAO, 2009, 2016). Following these indications, a survey was conducted in the field to identify pasture phytophysiognomies in the studied area, namely to characterize ground truth sites of healthy and degraded pasture. The procedure was repeated within the Serra Geral, Marilia, and Uberaba Formations. The ground truth points are identified in Figure 2 by the labeled green and red circles representing the healthy and degraded pastures in the three geologic formations, respectively. Figure 3 shows the healthy pasture in the rainy season [panel (c)] as green and tall grass with homogeneous coverage and the degraded pasture [panel (d)] with areas of exposed soil and the presence of invasive species and termite mounds.

The ground truth sites comprise 50 -meter buffers ( $0.7853 \mathrm{ha}$ ) centered on the point where the phytophysiognomy is the most representative. The six sites represented in Figure 2 were georeferenced with a Garmim GPSMAP 78 receiver. In each of these locations, four soil samples were collected randomly within the buffer at a depth of 0-0.2 $\mathrm{m}$ and used to perform chemical and physical analyses in a specialized laboratory. In addition, seven resistance to penetration tests were executed with the digital penetrometer PLG 1020 penetroLOG (Falker Automação, Porto Alegre, RS) at a depth of 0-0.6 m. The results of all these analyses and tests were presented in Valle Júnior et al. (2019).

\subsection{Vegetation indices and their automatic estimation in the Google Earth engine}

Having defined the chemical and physical characteristics of healthy and degraded pastures in the studied area (Section 2.3), the next step comprised the gathering of potentially related remote sensed data,

\begin{tabular}{lllcl}
\hline ID & Land use & Geologic formation & Pasture area (ha) & Geologic area (ha) \\
\hline 1 & Pasture & Marília & 4838.6 & 12954.6 \\
\hline 2 & Pasture & Uberaba & 16680.9 & 27179.9 \\
\hline 3 & Pasture & Serra Geral & 8355.8 & 12552.1 \\
\hline
\end{tabular}

TABLE 1 Pasture distribution per geologic formation in the environmental protection area of Uberaba River basin (EPA) and respective areas in hectares

Source: MapBiomas (2018) 
TAB LE 2 Compilation of geographic data used in the pasture degradation assessments

\begin{tabular}{|c|c|c|c|}
\hline Data type & Purpose of the data & Source & URL \\
\hline $\begin{array}{l}\text { Land use and cover map ( } 30 \times 30 \text { m pixel } \\
\text { size) generated from interpretation of } \\
\text { LANDSAT images in GEE, MAPBIOMAS } \\
\text { collection } 5.0\end{array}$ & Delineate the pasture area within the EPA & Google Earth engine (GEE) platform & $\begin{array}{l}\text { https://code.earthengine.google.com/ } \\
\text { be6e9e5570bee31fc5574758c627f709? } \\
\text { accept_repo=users\%2Fmapbiomas\% } \\
\text { 2Fuser-toolkit }\end{array}$ \\
\hline Geological map of Minas Gerais State & $\begin{array}{l}\text { Discriminate geologic formations within the } \\
\text { EPA }\end{array}$ & $\begin{array}{l}\text { State System of Environment and } \\
\text { Water Resources }\end{array}$ & http://idesisema.meioambiente.mg.gov.br/ \\
\hline $\begin{array}{l}\text { Time series of NDVI and RGB indices } \\
\text { within ground truth buffers }\end{array}$ & $\begin{array}{l}\text { Set up thresholds of degraded pasture } \\
\text { through regression analysis; compare } \\
\text { NDVI and RGB assessments of degraded } \\
\text { pasture through correlation and } \\
\text { sensitivity analyses }\end{array}$ & Sections 2.5 and 2.6 of present study & $\begin{array}{l}\text { https://code.earthengine.google.com/ } \\
\text { 85c7e8d6904f747ad848d11504bae53f }\end{array}$ \\
\hline $\begin{array}{l}\text { Time series of NDVI and RGB indices } \\
\text { within the EPA }\end{array}$ & $\begin{array}{l}\text { Produce NDVI- and RGB-based maps of } \\
\text { degraded pasture and perform crosstab } \\
\text { analysis }\end{array}$ & $\begin{array}{l}\text { Valle Junior et al. (2019); Sections } 2.5 \\
\text { and } 2.6 \text { of present study }\end{array}$ & $\begin{array}{l}\text { https://code.earthengine.google.com/ } \\
\text { e4a6f8aafd4216631d950a538fac3020 }\end{array}$ \\
\hline $\begin{array}{l}\text { Values of resistance to penetrations at field } \\
\text { checkpoints (Figure 2) }\end{array}$ & Validate the maps of degraded pasture & $\begin{array}{l}\text { Sections } 2.3 \text { and } 2.7 \text { of the present } \\
\text { study }\end{array}$ & \\
\hline
\end{tabular}

FIGURE 3 Visible characteristics of pasture phytophysiognomies as observed in the environmental protection area of Uberaba River basin (EPA). Panels (a) and (c) illustrate the healthy pasture in the dry and rainy periods, respectively; panels (b) and (d) the degraded pasture in the same periods [Colour figure can be viewed at wileyonlinelibrary.com]
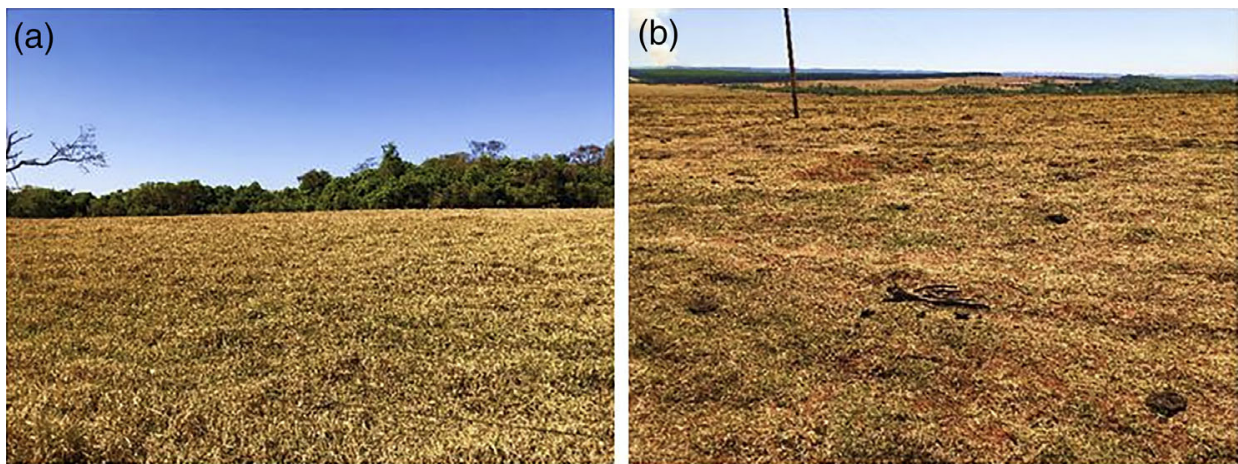

(c)
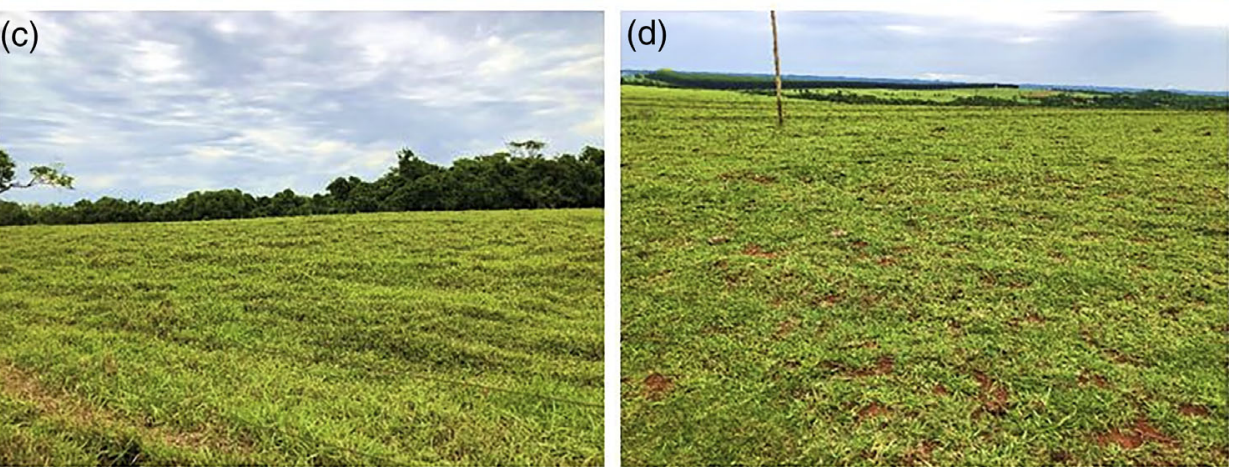

namely vegetation indices. The NDVI was used as a reference because of its wide applicability in similar studies, including in the detection of degraded pastures in the studied area (Valle Júnior et al., 2019). In addition, three new indices were used for comparison, based on the visible spectrum of light. These new vegetation indices were modified from the color index (Cl) of Woebbecke et al. (1995) and called total brightness quotients of blue (TBQB), green (TBQG), and red (TBQR). The equations used to estimate the NDVI and the RGB indices were as follows:

$$
N D V I=\frac{N I R-R e d}{N I R+R e d}
$$

$$
\begin{aligned}
\mathrm{TBQB} & =\frac{\text { Blue }}{(\text { Red }+ \text { Green })} \\
\mathrm{TBQG} & =\frac{\text { Green }}{(\text { Red }+ \text { Blue })} \\
\mathrm{TBQR} & =\frac{\text { Red }}{(\text { Blue }+ \text { Green })}
\end{aligned}
$$

Theoretically, the TBQs range from 0 to infinity, providing that both the numerator and denominator are not zero simultaneously. The idea behind the TBQs was to linearize the $\mathrm{Cl}$ index over the full range of $\mathrm{B}$, $\mathrm{R}$, and $\mathrm{G}$, improving its sensibility to changes in the color of 
vegetation, which was fully accomplished. Equations (2)-(4) differ from the $\mathrm{B}, \mathrm{G}$, and $\mathrm{R}$ equations proposed for the $\mathrm{Cl}$ [Equations (5)-(7) below] because they remove from the denominator the target band's influence. This simple modification improved the detection of degraded pastures, as will be demonstrated in the results section.

$$
\begin{aligned}
& \mathrm{B}=\frac{\text { Blue }}{(\text { Red }+ \text { Green }+ \text { Blue })} \\
& \mathrm{G}=\frac{\text { Green }}{(\text { Red }+ \text { Blue }+ \text { Green })} \\
& \mathrm{R}=\frac{\text { Red }}{(\text { Blue }+ \text { Green }+ \text { Red })}
\end{aligned}
$$

The vegetation indices were estimated at the ground truth sites of Figure 2 and within the pasture areas of EPA. In the first case, the estimation aimed to obtain NDVI, TBQB, TBQG, and TBQR values that could represent the healthy and degraded pastures developed on the Serra Geral, Marilia, and Uberaba geologic Formations considering their variations with season. Put another way, in this case, the aim was to typify healthy and degraded pastures based on the vegetation indices. In the second case, the procedure aimed to obtain NDVI, TBQB, TBQG, and TBQR values within the pasture areas and classify them as healthy or degraded through comparison of actual and typical values, i.e. assessed on a pasture site and on a ground truth site, respectively.

The procedures outlined in the previous paragraphs are illustrated in Figure 4 and identified as 'zonal statistics' and 'coincidence map'" in that figure. They were implemented over 32 images from the LANDSAT-8 OLI/T1_SR relative to a 3-year period (2017, 2018, and 2019), and repeated for the Serra Geral, Marília, and Uberaba Formations. Given the huge amount of data to process and the complex operations to undertake, the generation of zonal statistics and coincidence maps was accomplished with a routine written in JAVASCRIPT programming language in the Google Earth engine (GEE) code editor menu (GEE, 2020; Gorelick et al., 2017). The first script is available at: https://code.earthengine.google.com/85c7e8d6904f747ad848d11504bae53f

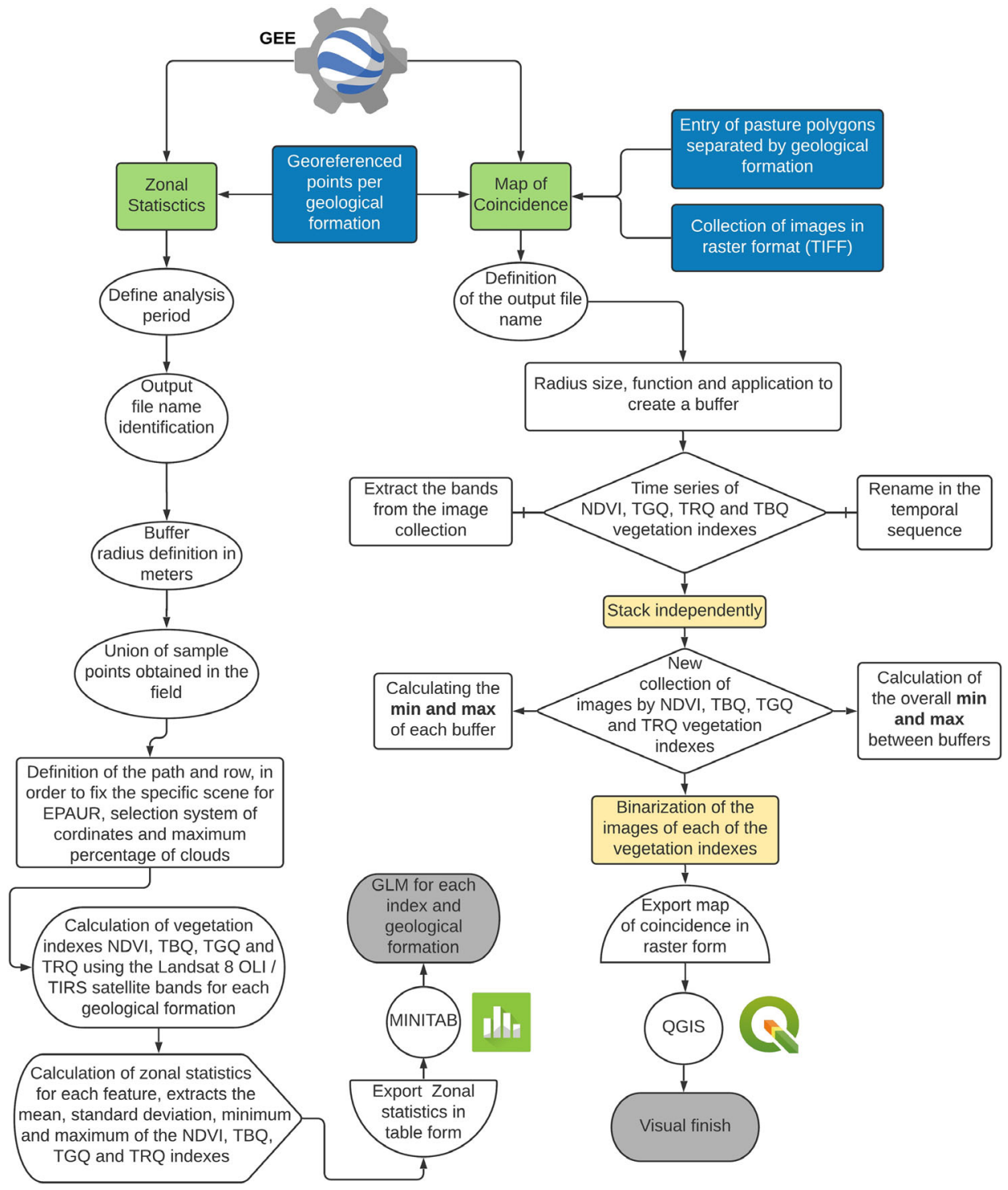

FIGURE 4 Flowchart of Google Earth engine scripts. Additional information in the text and operational details in the Data S1, Section A [Colour figure can be viewed at wileyonlinelibrary.com] 
and the second at: https://code.earthengine.google.com/e4a6f8a afd4216631d950a538fac3020.

In brief, the routines facilitated the search for images and enabled their automatic cropping based on the area of interest. They allowed to filter the data according to a predefined period (e.g., 2017-2019) and atmospheric conditions (e.g., $<30 \%$ of clouds) followed by the calculation of NDVI, TBQB, TBQG, and TBQR scores. Finally, they could be used to extract zonal statistics and export the results in raster and spreadsheet formats for further statistical and spatial modeling in MINITAB $19^{\circledR}$ and QGIS, respectively. The operational details relative to the GEE scripts are described in the Data S1-Supplementary Materials, Section A.

\section{5 | Maps of degraded pasture}

The GEE scripts generated data to draw 12 maps of degraded pasture, considering the four indices (NDVI, TBQB, TBQG, and TBQR) and the three Formations (Serra Geral, Marilia, and Uberaba) used in the assessments. Each map was drawn considering the number of matches between the vegetation index of a pasture location and the range of index scores representing a degraded pasture, evaluated at the ground truth sites (Figure 2). The maximum number of matches would be 32 , equal to the number of images used in the analysis. However, the pasture location was considered degraded when the number of matches was four or more, as proposed in Valle Júnior et al. (2019).

The ranges of NDVI, TBQB, TBQG, and TBQR scores representing a healthy or a degraded pasture were defined in a general linear model (GLM) implemented in the MINITAB 19 software. As previously, the procedure was replicated for every geologic formation. The indices were plotted as function of time (the 32 images represent an equal number of moments within the 3-year period) and fitted to cubic polylines. The index-versus-time diagrams derived therefrom were completed with $95 \%$ confidence bands allowing to estimate a SD between real and fitted values. When evaluating a pasture location within the EPA at a given time, the indices assessed at that point were plotted in the diagrams. The location was provisionally set to healthy or degraded pasture at that time if the indices fell between the confidence bands (positive match) in the respective diagram. The final assignment to healthy or degraded pasture occurred when the number of positive matches reached $\geq 4$.

\section{6 | Relationship between the NDVI and the RGB indices}

The relationship between the time series of NDVI and the corresponding records of TBQB, TBQG, and TBQR were determined by correlation, sensitivity, and crosstab analyses. Correlation analysis resorted to the Spearman correlation coefficient. A significant coefficient would reveal consistency between the NDVI and the RGB indices. The sensitivity analysis was based on the method of Gitelson (2004):

$$
\begin{aligned}
& \mathrm{Sb}=\frac{\mathrm{d}(\mathrm{TBQB})}{\mathrm{d}(\mathrm{NDVI})} \times\left(\frac{1}{\frac{\Delta \mathrm{TBQB}}{\Delta \mathrm{NDVI}}}\right) \\
& \mathrm{Sg}=\frac{\mathrm{d}(\mathrm{TBQG})}{\mathrm{d}(\mathrm{NDVI})} \times\left(\frac{1}{\frac{\Delta \mathrm{TBQG}}{\Delta \mathrm{NDVI}}}\right) \\
& \mathrm{Sr}=\frac{\mathrm{d}(\mathrm{TBQR})}{\mathrm{d}(\mathrm{NDVI})} \times\left(\frac{1}{\frac{\Delta \mathrm{TBQR}}{\Delta \mathrm{NDVl}}}\right)
\end{aligned}
$$

Where: $\mathrm{Sb}, \mathrm{Sg}$, and $\mathrm{Sr}$ are the sensitivities of TBQB, TBQG, and TBQR, respectively, relative to the $N D V I ; d(N D V I), d(T B Q B), d(T B Q G)$, and $d(T B Q R)$ are the first derivatives of Equations (1)-(4), respectively; $\triangle \mathrm{NDVI}=\mathrm{NDVImax}-\mathrm{NDVImin}, \triangle \mathrm{TBQB}=\mathrm{TBQBmax}-\mathrm{TBQBmin}$, $\triangle \mathrm{TBQG}=\mathrm{TBQGmax}-\mathrm{TBQGmin}$ and $\triangle \mathrm{TBQR}=\mathrm{TBQRmax}-$ $T B Q R m i n$, are the ranges of observed indices, meaning the differences between the maximum and minimum values of each index. According to Gitelson (2004), the $S$ values measure the capability of two vegetation indices to identify biophysical changes in plants. In the present study, when $S<1$, the NDVI was more sensitive than the RGB index; when $S=1$, the sensitivities between the indices were identical; and when $S>1$, the RGB index was more sensitive than the NDVI. Besides, if the time-series of NDVI or the time series of both vegetation indices were stationary (no temporal trends, meaning derivative terms equal to zero), then the $S$ values could not be calculated. If the time series were both nonstationary, then the $S$ values would be positive when the two trends were increasing or decreasing and negative otherwise. Finally, for a nonstationary NDVI and a stationary RGB series, $S=0$. The crosstab analysis estimated the spatial coincidence between areas classified as degraded by the NDVI and the RGB indices. Larger coincidences represented a closer relationship between the classifications. The crosstab analysis was restored to the CROSSTAB tool of QGIS 3.10.5.

\section{7 | Field validation of remote sensed pasture degradation maps}

The resistances to penetration of a degraded pasture in the Serra Geral, Marília, and Uberaba geological formations were compiled from Valle Júnior et al. (2019) and are as follows: $4428.5 \pm 1271.2 \mathrm{kPa}$, $5418.3 \pm 700.5 \mathrm{kPa}$, and $5464.9 \pm 1037.3 \mathrm{kPa}$, respectively. These values were obtained at the ground truth sites of Figure 2 . While validating the classification of degraded pastures based on the NDVI, those authors measured the resistance to penetration in the checkpoints also plotted in Figure 2, distributed as follows: 15 in the Serra Geral Formation, 4 in the Marília Formation, and 19 in the Uberaba Formation. These measurements allowed to classify the checkpoints as healthy or degraded pasture and to compare this filed-based classification with the NDVI-based classification. The results indicated $84.1 \%$ of positive matches. In the present study, a similar procedure was used to compare the field-based classification at the checkpoints with the TBQB, TBQG, and TBQR classifications. 


\section{3 | RESULTS}

\section{1 | Vegetation index signatures of healthy and degraded pastures}

The regression models that describe the temporal variations of NDVI, TBQB, TBQG, and TBQR are illustrated in Figure 5a-d. The top, middle, and bottom panels represent the signatures of pastures located in the Serra Geral, Marilia, and Uberaba Formations, while the left-hand side and right-hand side panels represent the signatures of degraded and healthy pastures, respectively. The cubic fittings to all indices were significant at $p<0.05$ for all geological formations. According to Sanchez (2013), the fittings to the NDVI, TBQG, and TBQR showed strong (49\%-81\%) to very strong (81\%-98\%) adjusted (a)

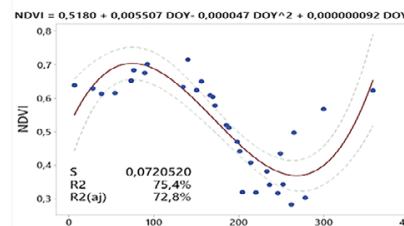

(a1)

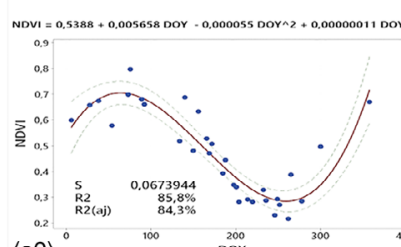

(a2)

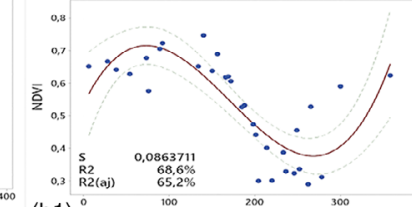

$(\mathrm{b} 1)^{\circ}$

$\underset{\substack{200 \\ \text { Dor }}}{200}$

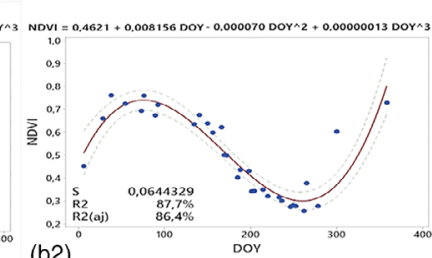

(b2)

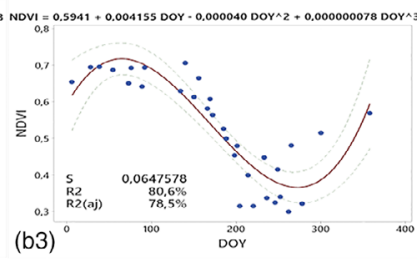

(c)
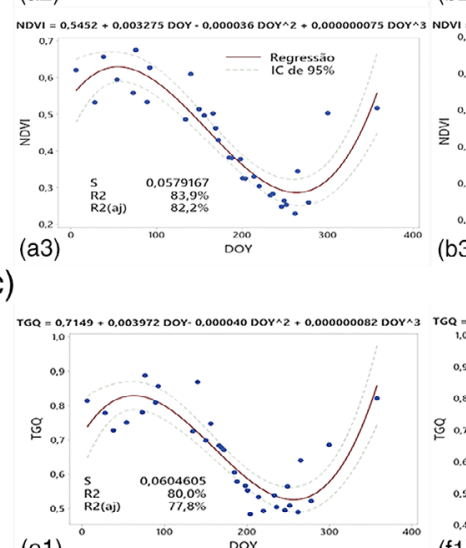

(e1) 200

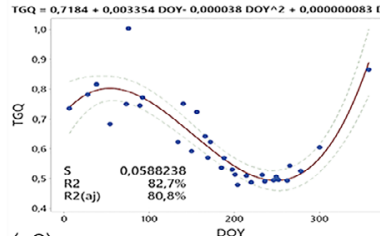

(e2)

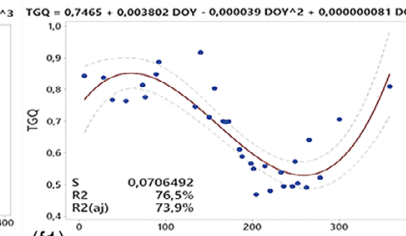

$(\mathrm{f} 1)$

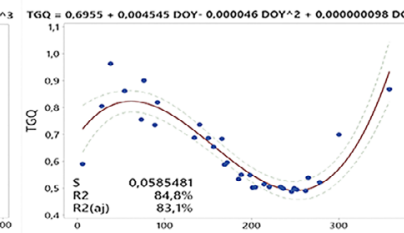

(†2)
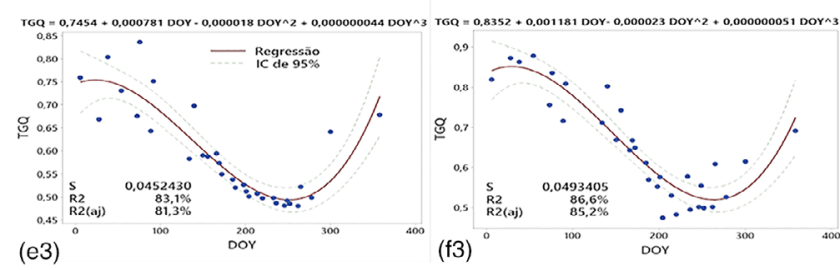

(b)

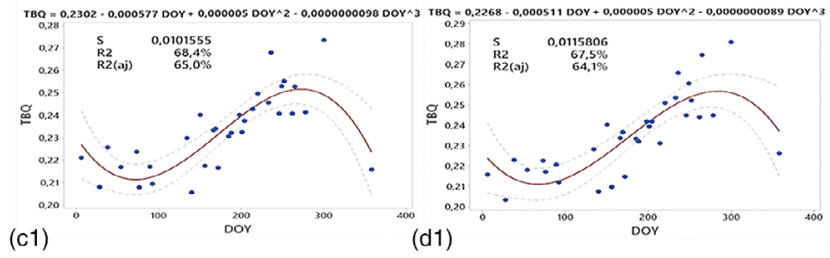

(c1)

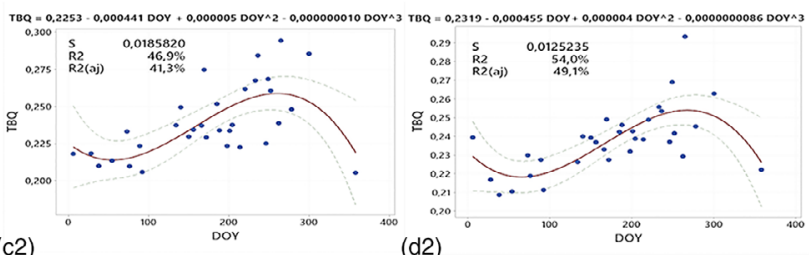

(c2)

(d2)

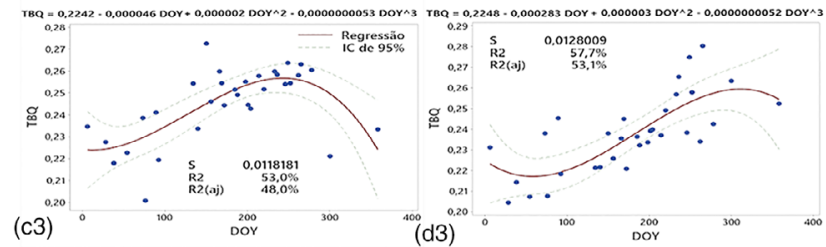

(d)

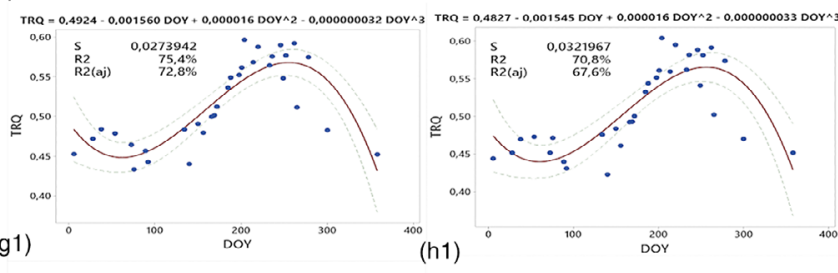

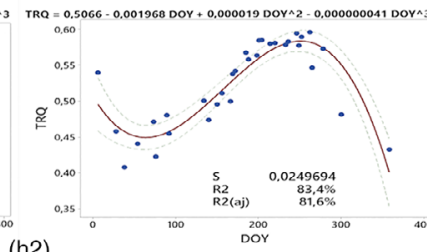

(h2)

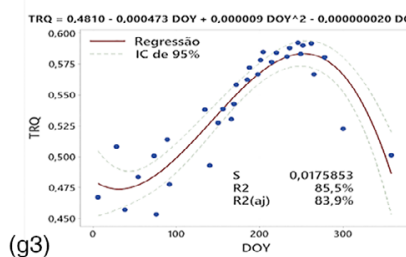

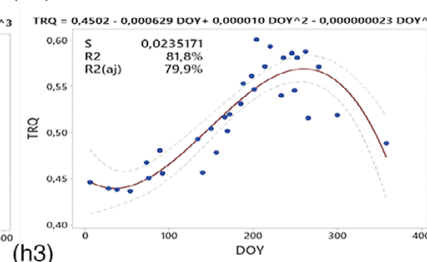

FI GURE 5 (a) Time-series of observed NDVI values and cubic regression with confidence interval used to predict the NDVI of pasture as function of geologic formation: (a1, b1) Serra Geral; (a2, b2) Marilia; (a3, b3) Uberaba. The left-hand side panels describe the NDVI versus time patterns of degraded pasture, and the right-hand side panels describe the patterns of healthy pasture. (b) Time-series of observed TBQB values and cubic regression with confidence interval used to predict the TBQB of pasture as function of geologic formation: (c1, d1) Serra Geral; (c2, d2) Marilia; (c3, d3) Uberaba. The lefthand side panels describe the TBQB versus time patterns of degraded pasture, and the right-hand side panels describe the patterns of healthy pasture. (c) Time-series of observed TBQG values and cubic regression with confidence interval used to predict the TBQG of pasture as function of geologic formation: (e1, f1) Serra Geral; (e2, f2) Marilia; (e3, f3) Uberaba. The left-hand side panels describe the TBQG versus time patterns of degraded pasture, and the right-hand side panels describe the patterns of healthy pasture. (d) Time-series of observed TBQR values and cubic regression with confidence interval used to predict the TBQR of pasture as function of geologic formation: (g1, h1) Serra Geral; (g2, h2) Marilia; (g3, h3) Uberaba. The left-hand side panels describe the TBQR versus time patterns of degraded pasture, and the right-hand side panels describe the patterns of healthy pasture 
coefficients of determination ( $R^{2}$ aj.), while the fittings to the TBQB showed medium (9\%-49\%) to strong $\mathrm{R}^{2}$ aj. In addition to the high $\mathrm{R}^{2} \mathrm{aj}$ linked to most fittings, the SDs of the distance between observed and fitted values ( $S$ values in Figure $5 a-d$ ) were generally low, indicating a close response of vegetation indices to seasonality (Araujo, 2019). The complete list of $R^{2}$ aj and $S$ values relative to the cubic fittings is presented in Tables S1a-d of Data S1, Section B.

\section{2 | Correlation between time-series of NDVI and RGB indices}

The Spearman correlations between the time series of NDVI and the corresponding records of TBQB, TBQG, and TBQR were significant at $p<0.05$ for all geological formations, but were positive for the TBQG and negative for the TBQB and TBQR. The respective values were $-0.794,0.965$, and -0.956 for the Serra Geral Formation; $-0.524,0.966$, and -0.966 for the Marília Formation; -0.723 , 0.989, and -0.984 for the Uberaba Formation. According to
Martins and Domingues (2014), these scores represent excellent (0.9-1.0) associations with the NDVI in the case of TBQG and TBQR, and low (0.4-0.6) to medium (0.6-0.8) associations in the case of TBQB.

\section{3 | Performance of total brightness indices relative to the color index}

As determined in Section 3.2, the time series of NDVI and TBQG were the most resemblant (highest positive Spearman correlation coefficient). These records were plotted in Figures S1a-f along with the time-series of $\mathrm{G}$ [Equation (6)], while the corresponding descriptive statistics are depicted in Table S2a-c (Data S1, Section C). In all geologic formations, the $G$ diagrams deviate farther from the corresponding NDVI graphs than the TBQG diagrams. Besides, the amplitudes of NDVI and TBQG were much closer than the amplitudes of $\mathrm{G}$. These findings indicate less capability of $\mathrm{G}$ to capture biophysical changes in pasture than the TBQG. (a)

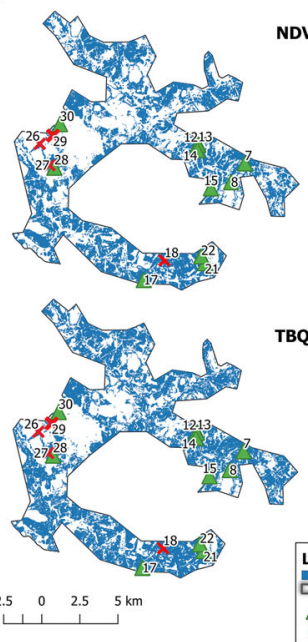

(c)
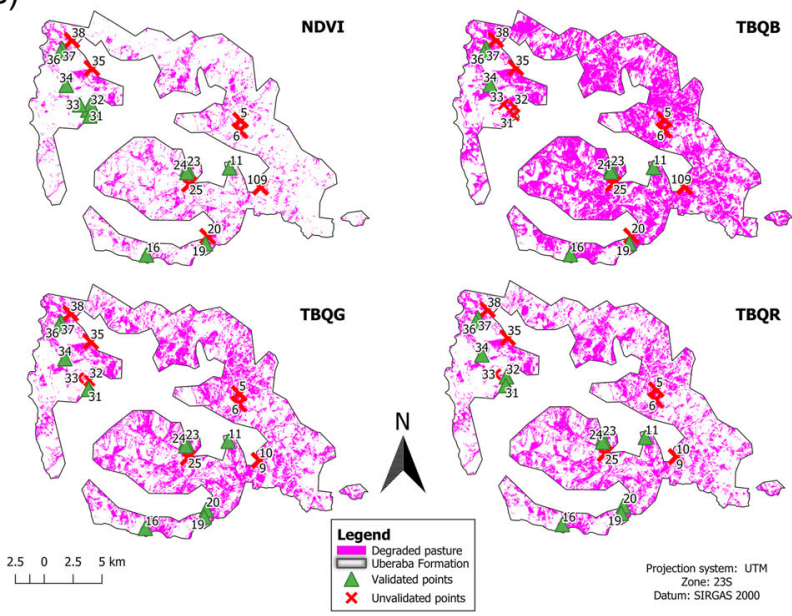

(b)
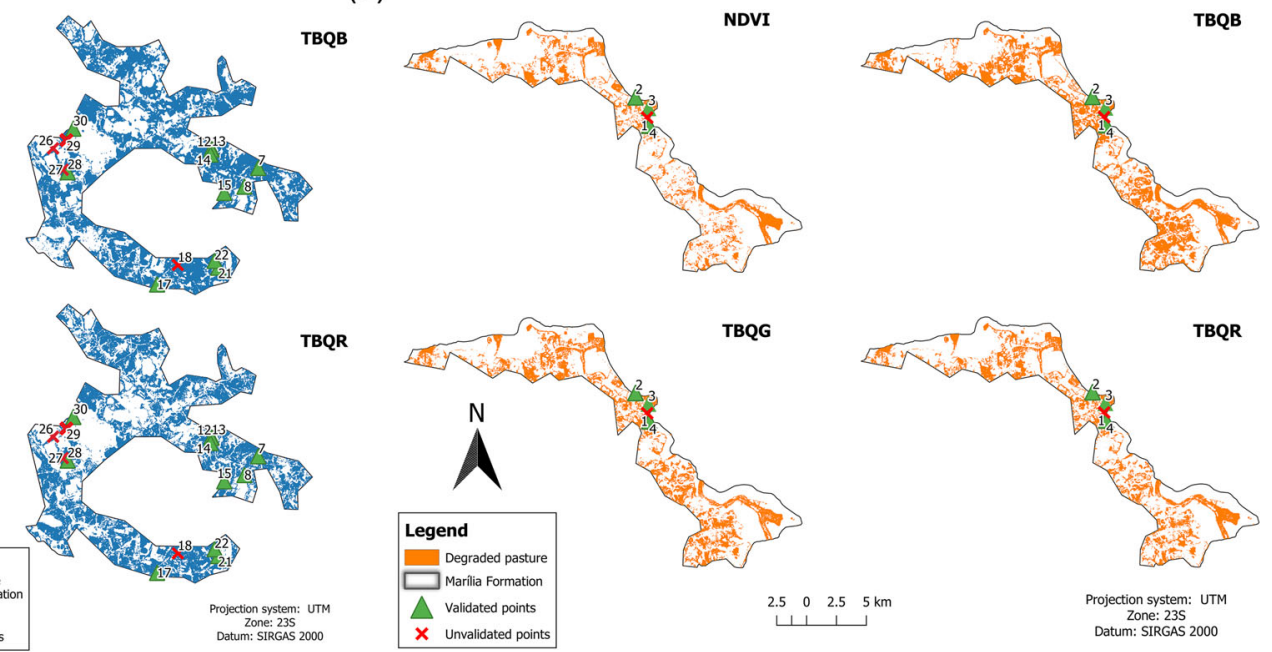

TBQG

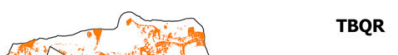

TBQR
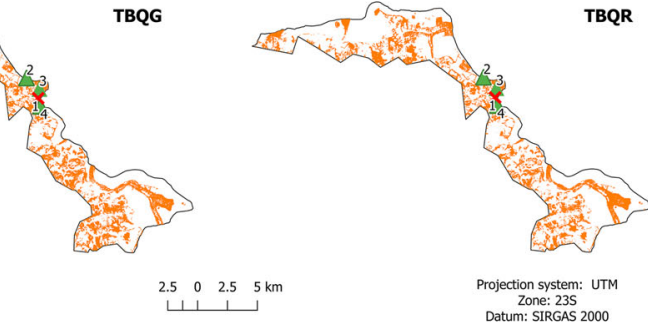

FIGURE 6 Maps of degraded pasture within the EPA: (a) in the Serra Geral Formation; (b) in the Marilia Formation; in the Uberaba Formation 


\section{4 | Maps of degraded pastures, sensitivity analysis, and field validation}

The maps of degraded pasture are illustrated in Figure 6a-c for the Serra Geral, Marília, and Uberaba Formations as determined by the NDVI, TBQB, TBQG, and TBQR vegetation indices, with the indication of checkpoints where the label degraded was confirmed or infirmed in the field. The corresponding distributions of positive matches are portrayed in Figure S2a-c (Data S1, Section D). These figures provide an illustration of where the classification of degraded is more probable. The areas occupied by degraded pasture are depicted in Table 3 with discrimination of geologic formation and vegetation index. The global estimations indicate 12,066.9, 25,180.1, 18,985.3, and 17,486.3 hectares of degraded pasture as diagnosed by the NDVI, TBQB, TBQG, and TBQR indices, respectively. This represents $41.2 \%$, $86.0 \%, 64.8 \%, 59.7 \%$ of all pasture area present in the EPA. The larger values reported for TBQB, TBQG, and TBQR reveal a stronger perception of degradation by the RGB indices relative to the NDVI. The differences between the areas of degraded pasture estimated by the RGB indices relative to the corresponding areas estimated by the NDVI are depicted in Table S3 (Data S1, Section E).

The sensitivity of RGB indices relative to the NDVI [Sb, Sg, Sr; Equations (8)-(10)] was calculated within the Serra Geral, Marilia, and Uberaba Formations and produced the following results: $-0.67,0.77$, and -0.75 for the $\mathrm{Sb} ;-0.51,0.65$, and -0.68 for the Sg; and -0.08 , 0.29 , and -0.46 for the Sr. In all cases, $S<1$, meaning that the NDVI was the most sensitive index. The combined display of NDVI and RGB indices in the same diagram is presented in Figures S3a-5a for degraded pastures located in the Serra Geral, Marília, and Uberaba Formations, respectively, and in Figures $\mathrm{S} 3 \mathrm{~b}-5 \mathrm{~b}$ for healthy pastures located in the same regions (Data S1, Section E). These diagrams allowed comparing amplitudes and trends in the time series and hence understanding the $\mathrm{Sb}, \mathrm{Sg}$, and $\mathrm{Sr}$ results.

The sensitivity results helped explaining the larger areas attributed to degraded pasture by the RGB indices. Their lower sensitivities (also revealed in the wider confidence bands of Figure $5 b-d$ relative to those in Figure $5 \mathrm{a}$ ) increased the number of positive matches used to diagnose pasture degradation (Section 2.5), leading to an increase in the area of mapped degraded pasture. The good news is that the lowering of sensitivity has not reduced the performance of validation, i.e. the comparison of remote sensed and field classifications of pasture degradation at the checkpoints of Figure 2. Indeed, the percentages of positive matches were $65.79 \%$ with NDVI, $60.53 \%$ with TBQB, $65.79 \%$ with TBQG, and $65.79 \%$ with TBQR. In all cases, this can be seen as substantial agreement (Landis \& Koch, 1977) and point to areas of degraded pasture in the EPA larger than those reported in Valle Júnior et al. (2019).

\subsection{Cross-tabulation results}

The cross tabulation of regions representing a degraded pasture assessed by the RGB indices with those assessed by the NDVI in the Serra Geral, Marília, and Uberaba Formations (Figures 6a-c) produced the results listed in Table 4. The percentage of coincidence among the classifications was no less than $87 \%$ regardless of the formation, which is remarkable.

\section{4 | DISCUSSION}

The total brightness quotient of the blue, green, and red spectral bands has captured the characteristics of pasture phytophysiognomies (healthy and degraded), which responded differently to seasonal changes of weather parameters (e.g., precipitation) and spatial changes of geologic substratum. The influence of season on the patterns of vegetation index time series is most probably a consequence of changes in the plant's chlorophyll concentrations that can occur between dry and rainy periods. In general, water stresses commonly observed in the dry period push down the chlorophyll concentrations

\begin{tabular}{|llcccc|}
\hline Vegetation index & Geologic Formation & $\mathbf{A}_{\mathbf{g}}(\mathbf{h a})$ & $\mathbf{A}_{\mathbf{p}}$ (ha) & $\mathbf{A}_{\mathbf{d p}}$ (ha) & $\mathbf{A}_{\mathbf{d p}}$ (\%) \\
\hline NDVI & Serra Geral & 12,552 & 8183 & 5803 & 70.9 \\
& Marília & 12,955 & 4883 & 2652 & 54.3 \\
\hline TBQB & Uberaba & 27,180 & 16,220 & 3612 & 22.3 \\
\hline & Serra Geral & 12,552 & 8183 & 6792 & 83.0 \\
\hline TBQG & Marília & 12,955 & 4883 & 4196 & 85.9 \\
& Uberaba & 27,180 & 16,220 & 14,193 & 87.5 \\
\hline TBQR & Serra Geral & 12,552 & 8183 & 6607 & 80.7 \\
& Marília & 12,955 & 4883 & 3644 & 74.6 \\
& Uberaba & 27,180 & 16,220 & 8734 & 53.8 \\
\hline & Serra Geral & 12,552 & 8183 & 6212 & 75.9 \\
\hline & Marília & 12,955 & 4883 & 3274 & 67.1 \\
\hline
\end{tabular}

TABLE 3 Area of degraded pasture within the Serra Geral, Marília, and Uberaba Formations, as determined by the NDVI, TBQB, TBQG, and TBQR vegetation indices

Note: symbols: $A_{g}$-area occupied by the geologic formation. $A_{p}$-area occupied by pasture; $A_{d p}-$ area occupied by degraded pasture 
TABLE 4 Results of cross-tabulation analysis

\begin{tabular}{|c|c|c|c|c|}
\hline & \multicolumn{4}{|c|}{ Number of pixels representing degraded pasture in the NDVI and RGB classifications simultaneously } \\
\hline \multicolumn{5}{|l|}{ Serra Geral } \\
\hline NDVI & 5803 & 5052 & 5143 & 5308 \\
\hline$\%$ Intersection & $100.00 \%$ & $87.05 \%$ & $88.63 \%$ & $91.47 \%$ \\
\hline \multicolumn{5}{|l|}{ Marília } \\
\hline$\%$ Intersection & $100.00 \%$ & $90.50 \%$ & $90.44 \%$ & $92.12 \%$ \\
\hline \multicolumn{5}{|l|}{ Uberaba } \\
\hline NDVI & 3612 & 3331 & 3231 & 3268 \\
\hline$\%$ Intersection & $100.00 \%$ & $92.22 \%$ & $89.43 \%$ & $90.46 \%$ \\
\hline
\end{tabular}

(Jain et al., 2007; Merzlyak et al., 2003; Schlemmer et al., 2005; Vigneau et al., 2011). Low concentrations favor the reflectances of red and blue bands because chlorophyll molecules present in the plant cells absorb these bands better than the green band (Jacquemoud \& Ustin, 2008; Taiz \& Zeiger, 2017). The rainy period reverses the water stress raising the chlorophyll contents and concomitantly the green band reflectances over the other bands (Katsoulas et al., 2016). This general pattern was observed in the present study. Figure $5 a-d$ shows a general tendency to decrease the TBQG and NDVI in the dry season and increase the TBQR concomitantly. In addition, the TBQB followed the pattern of TBQR. Finally, the patterns of all indices were mirrored in the rainy season, with the TBQG and NDVI showing an increase and the TBQR and TBQB a decrease. The drop of TBQG and NDVI in the dry period, in addition to the seasonal factors, could have been further influenced by the leaf thickness and LAI (Katsoulas et al., 2016; Peñuelas \& Filella, 1998).

The dependence of vegetation index time-series on geology was probably related to the different contents of iron oxides present in the clay fraction of soils derived from the Serra Geral Basalts and from the Marília and Uberaba Formation conglomerates, sandstones, siltstones, mudstones, and paleosols (Batezelli, 2015; CPRM, 2014; UFV, 2010), which may have influenced their spectral response (Karmanova, 1981; Pearlshtien \& Ben-Dor, 2020). Spectral data have efficiently identified the presence of Fe(III) in soils in various studies (Sánchez-Marañón et al., 2018), and a small variation in the percentage of iron-bearing minerals in the soils was found enough to change their spectral responses (Meneses et al., 2019). It is, therefore, likely to justify the heterogeneous behavior of geologic formations relative to spectral response on the basis of their iron contents. The concentrations of iron oxides in soils derived from the Serra Geral Formation (Silva et al., 2020), related to the presence of hematite in the clay fraction (Melo et al., 2003), may have also promoted better soil aggregation and water use (Correa et al., 2008) resulting in lower resistance to penetration. The consequences for the validation step were not apparent, but the result brings attention to the role of iron in future developments of Valle Júnior et al. (2019) method.

The dependence of pasture degradation assessments on geology is challenging to the method of Valle Júnior et al. (2019), because the future evaluations outside the Serra Geral, Marília, and Uberaba Formations will need a prior characterization of pasture phytophysiognomies in the new formations (e.g., the generation of regression models like those represented in Figure $5 a-d)$. It is worth recalling, however, the substantial coverage of the Mining Triangle region by the Serra Geral, Marília, and Uberaba Formations, where degradation of pastures affects 1.67 Mha (Brito et al., 2018). In this region, the use of Valle Júnior et al. (2019) method in the prognosis of pasture degradation would be an important asset for the restoration of pastureland.

The method of Valle Júnior et al. (2019) has recently become the basis of a software used by the Public Ministry of Minas Gerais state to help identifying and promoting the recovery of degraded pastures in the Uberaba River basin. The software is called SIPADE (https://www.mpmg.mp.br/comunicacao/noticias/mpmg-integra-

comissao-de-meio-ambiente-do-cnmp.htm) and embeds the pasture areas classified as degraded by the method within the basin, discriminated as function of geologic formation. For rural properties overlapping these pasture areas, an alert is emitted, and the authorities check degradation in the property through the testing penetration resistance in a set of random points. If pasture degradation is confirmed, a report is emitted, and the landowner is encouraged to recover the pasture or pay the authorities to do so. The use of SIPADE is effective, but the use of NDVI-based maps of degraded pasture should be revisited in the future. Firstly, the RGB-based maps presented in this study have enlarged the areas of degraded pasture relative to the NDVI-based areas of Valle Júnior et al. (2019), without reducing the validation performances, meaning that they are more conservative and hence can help mitigating degradation more widely. Secondly, the use of RGB-based maps would allow mapping pasture degradation at very high resolutions based on images captured by RGB cameras installed in UAVs. Given the low cost of these cameras, the verification of degraded pastures by the authorities would expand at quicker rates and become more accurate. Thirdly, the verification process would become more transparent and hence recognized better by the landowners, because many of them would be capable to acquire and use UAVs and implement a self-verification based on their own images. 


\section{5 | IMPLICATIONS OF THIS STUDY}

The use of vegetation indices of the visible spectrum proposed in this work, combined with the application of remote sensing tools, was efficient in detecting degraded pastures within the EPA of Uberaba River basin located in the State of Minas Gerais, Brazil. The proposed method simplifies the mapping of degraded pasture without using the near-infrared band or reducing the performances of validation in the field through penetration resistance tests. The results showed more conservative assessments (larger areas) of pasture degradation based on the RGB indices relative to the NDVI counterparts, which is further motivation to use these visible spectrum indices as an official tool. Based on the innovation and findings of this study, it will be possible to implement pasture quality mapping using low-cost cameras embedded or present in UAVs and smartphones, accelerating and making more accurate the verification of degradation by the authorities. However, for detection of leaf water stresses, when the water volume in the soil is low, the plant goes into protection, preventing the diagnosis through visible spectrum vegetation indices (Katsoulas et al., 2016).

The identification of degraded pastures, which under Brazilian Law is treated as environmental damage (Federal Law 12.651/2012-Brazilian Forest Code), is expected to trigger the development of public policies that bring these areas back into the productive system (Valera et al., 2017). Pasture diagnosis is, therefore, a planning tool that helps in environmental compliance. Considering the very large areas occupied by degraded pastures in Brazil and the World, and the environmental consequences derived therefrom, it is paramount and urgent to implement verification actions in the field to enforce the correct use and occupation of land. The results of this study represent a significant contribution to this ambition.

\section{6 | CONCLUSIONS AND FUTURE WORK}

The use of visible spectrum vegetation indices TBQG and TBQR proved to be as efficient as the NDVI in the diagnosis of pasture quality from orbital satellite images at the local scale, showing that the area of degraded pasture in the EPA of Uberaba River basin (Minas Gerais, Brazil) varied between $41.20 \%$ and $64.83 \%$ of the total pasture area in the period 2017-2019. Thus, the sensitivity of total brightness quotients proved to be adequate for the spatial and temporal diagnoses of degraded pastures, with a better fit (e.g., $R^{2} a j, S$ ) for the TBQG. It is apparent the great potential of using the visible range indices to reveal the spatial and temporal dynamics of pastures. The use of these indices simplifies the mapping of degradation, favoring the use of lowcost cameras built-in or present in UAVs, orbital satellites, and smartphones. In the present study, the areas of degraded pasture detected by the total brightness quotients were larger than the NDVIbased areas. This is an additional argument to use the visible spectrum indices in official interventions for the restoration of pastures, because the area covered by them will be wider, ensuring better environmental compliance. To get even closer to environmental compliance, new studies will be necessary to assess pasture degradation through analysis of RGB indices retrieved from high-resolution images (e.g., captured by UAVs). The results would have an impact on precision agriculture through reduction of investment costs, namely the acquisition of equipment to monitor plant vigor through spectral analysis, enabling a closer monitoring of production systems and environmental impacts. The transposition of the method to geologic formations other than the Serra Geral, Marilia, and Uberaba geologic formations is also a challenge for future works. The generalization of the method to a more ample set of geologic formations would help expanding its applicability within the State of Minas Gerais, Brazil, and ultimately the entire Planet.

\section{ACKNOWLEDGMENTS}

The present study was carried out within the framework of Conselho Nacional de Desenvolvimento Científico e Tecnológico (CNPq), and of two CNPq active research groups, namely the "Política de Uso do Solo" (POLUS) and "Manejo Sustentável de Bacias Hidrográficas" (affiliated to the IFTM). The author affiliated to IFTM, Renato Farias do Valle Júnior, wishes to acknowledge the funding through the CNPq research scholarship Proc. 307921/2018-2. For the author integrated in the CITAB Research Centre, the research was further financed by the National Funds of FCT-Portuguese Foundation for Science and Technology, under the project UIDB/04033/2020. For the author integrated in the CQVR, the research was further financed by National Funds of FCT-Portuguese Foundation for Science and Technology, under the Project UIDB/00616/2020.

The authors declare no conflicts of interest. The funders had no role in the design of the study, in the collection, analyses, or interpretation of data, in the writing of the manuscript, or in the decision to publish the results.

\section{DATA AVAILABILITY STATEMENT}

The data that support the findings of this study are available on request from the corresponding author. The data are not publicly available due to privacy or ethical restrictions.

\section{ORCID}

Renato Farias do Valle Junior (DD https://orcid.org/0000-0003-07745788

Victor Peçanha de Miranda Coelho (D) https://orcid.org/0000-00030024-3304

Luís Filipe Sanches Fernandes (iD) https://orcid.org/0000-0002-94867160

Fernando António Leal Pacheco (iD) https://orcid.org/0000-0002-23995261

\section{REFERENCES}

Abdala, V. 2012. Diagnóstico hídrico do rio Uberaba-MG como subsídio para a gestão das áreas de conflito ambiental. Tese apresentada à Faculdade de Ciências Agrárias e Veterinárias-UNESP, Câmpus Jaboticabal, como parte das exigências para a obtenção do título Doutor em Agronomia, 76p.

Araujo, I. R. C. Irrigação com efluente tratado de abatedouro de aves sobre o solo e a produção florestal. Tese de Doutorado apresentada em 
regime cotutela aos Programa de Pós-Graduação em Engenharia Agrícola, da Universidade Estadual do Oeste do Paraná, área de Recursos Hídricos e Saneamento Ambiental, e Programa de Investigação Agrária e Florestal da Universidade Estadual do Oeste do Paraná, 79p.

Arroyo, J., Guijarro, M., \& Pajares, G. (2016). An instance-based learning approach for thresholding in crop images under different outdoor conditions. Computers and Electronics in Agriculture, 127, 669-679. https://doi.org/10.1016/j.compag.2016.07.018

Batezelli, A. (2015). Continental systems tracts of the Brazilian Cretaceous Bauru basin and their relationship with the tectonic and climatic evolution of South America. Basin Research, 29, 1-25. https://doi.org/10. 1111/bre.12128

Batista, P. H. D., de Almeida, G. L. P., da Silva, J. L. B., Pandorfi, H., Da Silva, M. V., da Silva, R. A. B., de Melo, M. V. N., Lins, F. A. C., \& Junior, J. J. F. C. (2020). Short-term grazing and its impacts on soil and pasture degradation. DYNA, 87, 123-128. https://doi.org/10.15446/ dyna.v87n213.81853

Beck, H. E., Zimmermann, N. E., McVicar, T. R., Vergopolan, N., Berg, A., \& Wood, E. F. (2018). Present and future Köppen-Geiger climate classification maps at $1-\mathrm{km}$ resolution. Scientific Data, 5, 1-12. https://doi. org/10.1038/sdata.2018.214

Beniaich, A., Silva, M. L. N., Avalos, F. A. P., de Menezes, M. D., \& Cândido, B. M. (2019). Determination of vegetation cover index under different soil management systems of cover plants by using an unmanned aerial vehicle with an onboard digital photographic camera. Semin: Ciências Agrárias, 40, 49. https://doi.org/10.5433/1679-0359. 2019v40n1p49

Brito, J. L. S., Rosa, R., Ferreira, V. O., Lima, E. F., \& Silva, M. K. A. (2018), Mapping and evaluation of the quality of pastures cultivated in the Triangulo Mineiro using OLI/Landsat-8 images. Caminhos de Geografia, 19(67), 68-82. https://doi.org/10.14393/RCG196705

Chen, Y., Fei, X., Groisman, P., Sun, Z., Zhang, J., \& Qin, Z. (2019). Contrasting policy shifts influence the pattern of vegetation production and C sequestration over pasture systems: A regional-scale comparison in temperate Eurasian steppe. Agricultural Systems, 176, 102679. https:// doi.org/10.1016/j.agsy.2019.102679

Córcoles, J. I., Ortega, J. F., Hernández, D., \& Moreno, M. A. (2013). Estimation of leaf area index in onion (Allium cepa L.) using an unmanned aerial vehicle. Biosystems Engineering, 115, 31-42. https://doi.org/10. 1016/j.biosystemseng.2013.02.002

Correa, M. M., Ker, J. C., \& Barrón, V. (2008). Caracterização de óxidos de ferro de solos do ambiente tabuleiros costeiros. Revista Brasileira de Ciencia do Solo, 32, 1017-1031.

CPRM-Companhia de Pesquisa de Recursos Minerais-CPRM, Serviço Geológico do Brasil. (2014). Mapa Geológico do Estado de Minas Gerais. Ministério de Minas e Energia-Secretaria de Geologia, vol. 1 (1000000). Mineração e Transformação Mineral. Brasília. Escala.

Cruz, L.B.S. (2003). Diagnostico ambiental da bacia hidrografica do Rio Uberaba-MG. Tese submetida à banca examinadora para obtenção do título Doutora em Eng. Agrícola na área Conc. em Água e Solo, (182p). Universidade Estadual de Campinas, Faculdade de Engenharia Agricola, Campinas, SP.

da Rocha Junior, P. R., Andrade, F. V., Mendonça, E. d. S., Donagemma, G. K., Fernandes, R. B. A., Bhattharai, R., \& Kalita, P. K. (2016). Soil, water, and nutrient losses from management alternatives for degraded pasture in Brazilian Atlantic rainforest biome. Science Total Environment, 583, 53-63. https://doi.org/10.1016/j.scitotenv. 2016.12.187

Davidson, E. A., Asner, G. P., Stone, T. A., Neill, C., \& Figueiredo, R. O. (2009). Objective indicators of pasture degradation from spectral mixture analysis of Landsat imagery. Journal of Geophysical Research Biogeosciences, 114, G00B03. https://doi.org/10.1029/2007JG000622

de Torres, F. N., Richter, R., \& Vohland, M. (2019). A multisensoral approach for high-resolution land cover and pasture degradation mapping in the humid tropics: A case study of the fragmented landscape of Rio de Janeiro. International Journal of Applied Earth Observation and Geoinformation, 78, 189-201. https://doi.org/10.1016/j.jag. 2019.01.011

EMBRAPA Territorial - Empresa Brasileira de Pesquisa Agropecuária Territorial 2018. Síntese ocupação e uso das terras no Brasil. https://www. embrapa.br/car/sintese. (acesso em 14 de outubro de 2020).

EMBRAPA-Empresa Brasileira de Pesquisa Agropecuária 2014. EMBRAPA mapeia degradação das pastagens do cerrado. Retrieved from https://www.embrapa.br/busca-de-noticias/-/noticia/2361250/ embrapa-mapeia-degradacao-das-pastagens-do-cerrado.

Euclides, V. P. B., do Valle, C. B., Macedo, M. C. M., Almeida, R. G., de Montagner, D. B., \& Barbosa, R. A. (2010). Brazilian scientific progress in pasture research during the first decade of XXI century. Revista Brasileira de Zootecnia, 39, 151-168. https://doi.org/10.1590/s151635982010001300018

FAO-Food and Agriculture Organization. (2009). Grassland index-A searchable catalogue of grass and forage legumes. Rome: Food and Agriculture Organization of the United Nations Retrieved from https:// web.archive.org/web/20081024221053/http://www.fao.org/ag/ AGP/AGPC/doc/Gbase/data/pf000187.htm

FAO-Food and Agriculture Organization, 2016. NASA SERVIR team learn about FAO monitoring software. Retrieved from http://www.fao.org/ forestry/news/91977/en/.

Fernandes, F. H. S., Sano, E. E., Ferreira, L. G., de Mello Baptista, G. M., Victoria, D. d. C., \& Fassoni-Andrade, A. C. (2018). Degradation trends based on MODIS-derived estimates of productivity and water use efficiency: A case study for the cultivated pastures in the Brazilian cerrado. Remote Sensing Applications: SocietyandEnvironment, 11, 3040. https://doi.org/10.1016/j.rsase.2018.04.014

GEE-Google Earth engine. (2020). Case studies. Retrieved from https:// earthengine.google.com/case_studies/.

Gitelson, A. A. (2004). Wide dynamic range vegetation index for remote quantification of biophysical characteristics of vegetation. Journal of Plant Physiology, 161, 165-173. https://doi.org/10.1078/0176-161701176

Gorelick, N., Hancher, M., Dixon, M., Ilyushchenko, S., Thau, D., \& Moore, R. (2017). Google Earth Engine: Planetary-scale geospatial analysis for everyone. Remote Sensing of Environment, 202, 18-27. https://doi.org/10.1016/j.rse.2017.06.031

IBGE-Instituto Brasileiro de Geografia e Estatística, 2020. Retrieved from https://censo2010.ibge.gov.br/sinopse/index.php?uf $=31 \&$ dados $=8$.

Imukova, K., Ingwersen, J., \& Streck, T. (2015). Determining the spatial and temporal dynamics of the green vegetation fraction of croplands using high-resolution RapidEye satellite images. Agricultural and Forest Meteorology, 206, 113-123. https://doi.org/10.1016/j.agrformet.2015. 03.003

Jacquemoud, S., \& Ustin, S. L. (2008). Modeling leaf optical properties. Photobiological sciences online. Environmental Photobiology Retrieved from http://photobiology.info/\#Environ

Jain, N., Ray, S. S., Singh, J. P., \& Panigrahy, S. (2007). Use of hyperspectral data to assess the effects of different nitrogen applications on a potato crop. Precision Agriculture, 8, 225-239. https://doi.org/10. 1007/s11119-007-9042-0

Jang, G., Kim, J., Yu, J.-K., Kim, H.-J., Kim, Y., Kim, D.-W., Kim, K.-H., Lee, C. W., \& Chung, Y. S. (2020). Review: Cost-effective unmanned aerial vehicle (UAV) platform for field plant breeding application. Remote Sensing, 12, 998. https://doi.org/10.3390/rs12060998

Jiang, H., Xu, X., Guan, M., Wang, L., Huang, Y., \& Jiang, Y. (2019). Determining the contributions of climate change and human activities to vegetation dynamics in agro-pastural transitional zone of northern China from 2000 to 2015. Science of the Total Environment, 718, 134871. https://doi.org/10.1016/j.scitotenv.2019.134871

Junges, A. H., Bremm, C., Fontana, D. C., de Oliveira, C. A. O., Schaparini, L. P., \& de Carvalho, P. C. F. (2016). Temporal profiles of 
vegetation indices for characterizing grazing intensity on natural grasslands in Pampa biome. Science in Agriculture, 73, 332-337. https://doi. org/10.1590/0103-9016-2015-0213

Karmanova, L. A. (1981). Effect of various iron compounds on the spectral reflectance and color of soils. Soviet Soil Science, 13, 53-60.

Karnieli, A., Bayarjargal, Y., Bayasgalan, M., Mandakh, B., Dugarjav, C., Burgheimer, J., Khudulmur, S., Bazha, S. N., \& Gunin, P. D. (2013). Do vegetation indices provide a reliable indication of vegetation degradation? A case study in the Mongolian pastures. International Journal of Remote Sensing, 34, 6243-6262. https://doi.org/10.1080/01431161. 2013.793865

Katsoulas, N., Elvanidi, A., Ferentinos, K. P., Kacira, M., Bartzanas, T., \& Kittas, C. (2016). Crop reflectance monitoring as a tool for water stress detection in greenhouses: A review. Biosystems Engineering, 151, 374398. https://doi.org/10.1016/j.biosystemseng.2016.10.003

Kim, S. L., Chung, Y. S., Ji, H., Lee, H., Choi, I., Kim, N., Lee, E., Oh, J., Kang, D.-Y., BAEK, J., Lee, G.-S., Kwon, T.-R., \& Kim, K.-H. (2019). New parameters for seedling vigor developed via phenomics. Applied Sciences, 9, 1752. https://doi.org/10.3390/app9091752

Landis, J. R., \& Koch, G. G. (1977). The measurement of observer agreement for categorical data. Biometrics, 33(1), 159-174.

LEMG-Lei Estadual de Minas Gerais $n^{\circ} 13.183 / 1999,1999$. Retrieved from https://documentacao.socioambiental.org/ato_normativo/UC/ 4482_20200510_223340.pdf.

Li, S., Verburg, P. H., Lv, S., Wu, J., \& Li, X. (2012). Spatial analysis of the driving factors of grassland degradation under conditions of climate change and intensive use in Inner Mongolia, China. Regional Environmental Change, 12, 461-474. https://doi.org/10.1007/s10113-0110264-3

Li, S., Yuan, F., Ata-UI-Karim, S. T., Zheng, H., Cheng, T., Liu, X., Tian, Y., Zhu, Y., Cao, W., \& Cao, Q. (2019). Combining color indices and textures of UAV-based digital imagery for rice LAl estimation. Remote Sensing, 11(15), 1763. https://doi.org/10.3390/rs11151763

Li, X., Gao, Z., Bai, L., \& Huang, Y. (2012). Potential of high resolution Rapideye data for sparse vegetation. In Geoscience and Remote Sensing Symposium (IGARSS), 2012 IEEE Int (pp. 420-423). Institute of Electrical and Electronics Engineers. https://doi.org/10.1109/IGARSS.2012. 6351548

Liu, J., \& Pattey, E. (2010). Retrieval of leaf area index from top-of-canopy digital photography over agricultural crops. Agricultural and Forest Meteorology, 150, 1485-1490. https://doi.org/10.1016/j.agrformet. 2010.08.002

Louhaichi, M., Borman, M. M., \& Johnson, D. E. (2001). Spatially located platform and aerial photography for documentation of grazing impacts on wheat. Geocarto International, 16, 65-70. https://doi.org/10.1080/ 10106040108542184

Lu, D., \& Weng, Q. (2007). A survey of image classification methods and techniques for improving classification performance. International Journal of Remote Sensing, 28, 823-870. https://doi.org/10.1080/ 01431160600746456

Macedo, M.C.M.., Zimmer, A.H.., Kichel, A.N.., Almeida, R.G.., Araujo, A.R., 2014. Degradação de pastagens, alternativas de recuperação e renovação, e formas de mitigação. Encontro adubaçao pastagens da Scot Consult.-Tec-Fértil. 158-181.

MapBiomas-MapBiomas General "Handbook" Algorithm Theoretical Basis Document (ATBD), 2019. Retrieved from https://mapbiomas-brsite.s3.amazonaws.com/ATBD_Collection_4_v2_Dez2019.pdf.

Marcial-Pablo, M. d. J., Gonzalez-Sanchez, A., Jimenez-Jimenez, S. I., Ontiveros-Capurata, R. E., \& Ojeda-Bustamante, W. (2019). Estimation of vegetation fraction using RGB and multispectral images from UAV. International Journal of Remote Sensing, 40, 420-438. https://doi.org/ 10.1080/01431161.2018.1528017

Martins, G. A., \& Domingues, O. (2014). Estatística Geral e Aplicada. 5a ed. rev. e ampl.. São Paulo, SP, Brazil: Atlas.
Melo, V. F., Corrêa, G. F., Maschio, P. A., Ribeiro, A. N., \& Lima, V. C. (2003). Importância das espécies minerais no potássio total da fração argila de solos do Triângulo Mineiro. Revista Brasileira de Ciência do Solo, 27, 09-10. https://doi.org/10.1590/S0100-0683200300050 0005

Meneses, P. R., De Almeida, T., \& Macedo, G. B. D. M. (2019). Reflectância dos materiais terrestres: análise e interpretação. São Paulo, SP, Brazil: Oficina de Textos.

Merzlyak, M. N., Gitelson, A. A., Chivkunova, O. B., Solovchenko, A. E., \& Pogosyan, S. I. (2003). Application of reflectance spectroscopy for analysis of higher plant pigments. Russian Journal of Plant Physiology, 50, 704-710. https://doi.org/10.1023/A:1025608728405

Meyer, G. E., \& Neto, J. C. (2008). Verification of color vegetation indices for automated crop imaging applications. Computers and Electronics in Agriculture, 63, 282-293. https://doi.org/10.1016/j.compag.2008. 03.009

Neves, A.K. (2017). Mineração de dados de sensoriamento remoto para detecção e classificação de áreas de pastagem na Amazônia Legal. Diss. (Mestrado em Sensoriamento Remoto)-Instituto Nacional de Pesquisas Espaciais, São José dos Campos, 2017.

Nishiyama, L. $(1998,1998)$. Procedimentos de mapeamento geotécnico como base para análises e avaliações ambientais do meio físico, em escala 1: 100.000: aplicação no município de Uberlândia-MG. UFSCar.

Novo, E. M. L. de M., Ponzoni, F. J. (2001). Introdução ao sensoriamento remoto, (pp. 1-68). Instituto Nacional de Pesquisas Espaciais, São José dos Campos.

Pearlshtien, D. H., \& Ben-Dor, E. (2020). Effect of organic matter content on the spectral signature of iron oxides across the VIS-NIR spectral region in artificial mixtures: An example from a red soil from Israel. Remote Sensing, 12(12), 1960. https://doi.org/10.3390/rs12121960

Peñuelas, J., \& Filella, I. (1998). Visible and near-infrared reflectance techniques for diagnosing plant physiological status. Trends in Plant Science, 3, 151-156. https://doi.org/10.1016/S1360-1385(98)01213-8

Postel, S. L. (1998). Water for food production: Will there be enough in 2025? Bioscience, 48, 629-637. https://doi.org/10.2307/1313422

Qiu, Z., Xiang, H., Ma, F., \& Du, C. (2020). Qualifications of rice growth indicators optimized at different growth stages using unmanned aerial vehicle digital imagery. Remote Sensing, 12, 1-18. https://doi.org/10. 3390/rs12193228

Sanchez, G. (2013). PLS path modeling with R. (p. 1-235). Berkeley, CA: Trowchez Editions.

Sánchez-Marañón, M., Cuadros, J., Michalski, J. R., Melgosa, M., \& Dekov, V. (2018). Identification of iron in earth analogues of Martian phyllosilicates using visible reflectance spectroscopy: Spectral derivatives and color parameters. Applied Clay Science, 165, 264-276. https://doi.org/10.1016/j.clay.2018.08.016

Schlemmer, M. R., Francis, D. D., Shanahan, J. F., \& Schepers, J. S. (2005). Remotely measuring chlorophyll content in corn leaves with differing nitrogen levels and relative water content. Agronomy Journal, 97, 106112. https://doi.org/10.2134/agronj2005.0106

Silva, L. S., Marques Júnior, J., Barrón, V., Gomes, R. P., Teixeira, D. D. B., Siqueira, D. S., \& Vasconcelos, V. (2020). Spatial variability of iron oxides in soils from Brazilian sandstone and basalt. Catena, 185, 104258. https://doi.org/10.1016/j.catena.2019.104258

Silva, G.C. da 2017. Detecção e contagem de plantas utilizando técnicas de inteligência artificial e machine learning. Trab. Conclusão curso submetido ao Departamento Eng. Elétrica e Eletrônica da Universidade Fedederal de Santa Catarina para a obtenção do título Bacharel em Engenharia Eletrônica, 94p.

Siqueira, H. E., Pissarra, T. C. T., do Valle Junior, R. F., Fernandes, L. F. S., \& Pacheco, F. A. L. (2017). A multi criteria analog model for assessing the vulnerability of rural catchments to road spills of hazardous substances. Environmental Impact Assessment Review, 64, 26-36. https:// doi.org/10.1016/j.eiar.2017.02.002 
Sun, B., Li, Z., Gao, W., Zhang, Y., Gao, Z., Song, Z., Qin, P., \& Tian, X. (2019). Identification and assessment of the factors driving vegetation degradation/regeneration in drylands using synthetic high spatiotemporal remote sensing data-A case study in Zhenglanqi, Inner Mongolia, China. Ecological Indicators, 107, 105614. https://doi.org/ 10.1016/j.ecolind.2019.105614

Taiz, L., \& Zeiger, E. (2017). Fisiologia e desenvolvimento vegetal, $6^{a}$ Edição. Porto Alegre, state of Rio Grande do Sul, Brazil: Artmed.

Townsend, C.R., Costa, N.L., Pereira, R.G.A., 2012. Recuperação e práticas sustentáveis de manejo de pastagens na Amazônia, Documentos, (Vol. 148, pp. 1-28). Porto Velho, RO: EMBRAPA Rondônia.

UFV-Universidade Federal de Viçosa. (2010). Mapa de solos do Estado de Minas Gerais (p. 49). Bello Horizonte: Fundação Estadual do Meio Ambiente Retrieved from http://www.dps.ufv.br/?page_id=742

Valera, C. A., Pissarra, T. C. T., Martins Filho, M. V., Valle Junior, R. F., Sanches Fernandes, L. F., \& Pacheco, F. A. L. (2017). A legal framework with scientific basis for applying the "polluter pays principle' to soil conservation in rural watersheds in Brazil. Land Use Policy, 66, 61-71. https://doi.org/10.1016/j.landusepol.20 17.04.036

Valle Júnior, R.F do, Siqueira, H.E., Valera, C.A., Oliveira, C.F., Sanches Fernandes, L.F., Moura, J.P., Pacheco, F.A.L., 2019. Diagnosis of degraded pastures using an improved NDVI-based remote sensing approach: An application to the environmental protection area of Uberaba River basin (Minas Gerais, Brazil). Remote Sensing Applications: Society and Environment 14, 20-33. https://doi.org/10.1016/j.rsase. 2019.02.001.

Vigneau, N., Ecarnot, M., Rabatel, G., \& Roumet, P. (2011). Potential of field hyperspectral imaging as a non destructive method to assess leaf nitrogen content in wheat. Field Crops Research, 122, 25-31. https:// doi.org/10.1016/j.fcr.2011.02.003

Wang, J., Xiao, X., Bajgain, R., Starks, P., Steiner, J., Doughty, R. B., \& Chang, Q. (2019). Estimating leaf area index and aboveground biomass of grazing pastures using Sentinel-1, Sentinel-2 and Landsat images.
ISPRS Journal of Photogrammetry and Remote Sensing, 154, 189-201. https://doi.org/10.1016/j.isprsjprs.2019.06.007

Wiesmair, M., Feilhauer, H., Magiera, A., Otte, A., \& Waldhardt, R. (2016). Estimating vegetation cover from high-resolution satellite data to assess grassland degradation in the Georgian Caucasus. Mountain Research and Development, 36, 56-65. https://doi.org/10.1659/MRDJOURNAL-D-15-00064.1

Woebbecke, D. M., Meyer, G. E., Von Bargen, K., \& Mortensen, D. A. (1995). Color indices for weed identification under various soil, residue, and lighting conditions. Transactions of the American Society of Agricultural Engineers, 38, 259-269. https://doi.org/10.13031/2013. 27838

Zhumanova, M., Mönnig, C., Hergarten, C., Darr, D., \& Wrage-Mönnig, N. (2018). Assessment of vegetation degradation in mountainous pastures of the Western Tien-Shan, Kyrgyzstan, using eMODIS NDVI. Ecological Indicators, 95, 527-543. https://doi.org/10.1016/j.ecolind. 2018.07.060

\section{SUPPORTING INFORMATION}

Additional supporting information may be found in the online version of the article at the publisher's website.

How to cite this article: da Silva Quinaia, T. L., do Valle Junior, R. F., de Miranda Coelho, V. P., da Cunha, R. C., Valera, C. A., Sanches Fernandes, L. F., \& Pacheco, F. A. L. (2021). Application of an improved vegetation index based on the visible spectrum in the diagnosis of degraded pastures: Implications for development. Land Degradation \&

Development, 1-15. https://doi.org/10.1002/ldr.4071 